\title{
CONSUMER ANXIETY, WELL-BEING and SOCIAL MEDIA USE: THE CASE OF \#HealthyNutrition
}

\author{
TÜKETICI KAYGISI, IYI-OLUŞ ve SOSYAL MEDYA: \#SağlıklıBeslenme
}

\author{
Ayla ÖZHAN DEDEOĞLU ${ }^{1}$ \\ Ezgi KABASAKAL ${ }^{2}$
}

\author{
https://orcid.org/0000-0002-0179-0644 \\ https://orcid.org/0000-0001-8204-1970
}

\begin{abstract}
The present study aims to describe the possible influence of social media content about healthy nutrition on consumer anxiety and well-being. In the literature there are insufficient numbers of scholarly studies that analyze consumer anxiety and well-being together, and particularly, on the basis of user-generated social media content about healthy nutrition. Understanding how user-generated social media content about healthy nutrition influences consumers' anxiety and well-being by shedding a light on both constructs can help the development of new theoretical explanations of functional and dysfunctional use of social media content and its consequences. The findings reveal that consumers do not feel so anxious due to the shared healthy nutrition contents and may have used these contents functionally for gratifications resulting in an increase of their well-being to a certain extent. Furthermore, posts on social media with healthy nutrition content generally have a positive effect on wellbeing. Considering the findings that indicate a low level of consumer involvement and relatively negative perceptions of the scientific validity of the content, recommendations for further studies are developed.
\end{abstract}

Keywords: consumer anxiety, consumer wellbeing, social media, healthy nutrition, functional use

\section{INTRODUCTION}

Due to the rise of critical consumption and financially empowered consumers, food supply chains have become more demand-oriented (Lowe et al.,

\section{ÖZET}

Mevcut çalışma, sosyal medyada yapılan sağlıklı beslenme içerikli paylaşımların tüketiciler üzerinde kaygı yaratma ya da iyi-oluşu artırma açısından olası etkilerini betimlemeyi amaçlamaktadır. Literatürde tüketici kaygısı ve iyi-oluşu bir arada ve özellikle de sağlıklı beslenme hakkında sosyal medya kullanıcılarınca yaratılan içerikler bağlamında inceleyen yeterli sayıda akademik çalışma bulunmamaktadır. Sağlıklı beslenme hakkında sosyal medyada kullanıcılarca yaratılan içeriklerin tüketici kaygıları ve iyi-oluşu nasıl etkilediğinin, her iki yapının boyutlarını derinlemesine analiz ederek incelenmesiyle söz konusu içeriklerin fonksiyonel olan ve olmayan kullanımları ve sonuçları hakkında yeni teorik açıklamalar geliştirmeye katkısı olacaktır. Çalışmada elde edilen bulgular, tüketicilerin sosyal medyadaki sağlıklı beslenme içerikleri nedeniyle çok fazla kaygı duymadıklarını ve bu içerikleri iyioluşlarını arttırmak için fonksiyonel olarak belli bir seviyede kullandıklarına işaret etmektedir. Ayrıca, sosyal medyada sağlıklı beslenme ile ilgili paylaşımların tüketicilerde genellikle iyi-oluşa olumlu etki ettiği tespit edilmiştir. Bununla birlikte, düşük tüketici ilgilenim düzeyi ve içeriklerin bilimsel geçerliliğine ilişkin kısmen olumsuz algılara işaret eden bulgular da dikkate alınarak gelecek çalışmalara ilişkin önerilerde bulunulmuştur.

Anahtar kelimeler: tüketici kaygısı, tüketici iyioluşu, sosyal medya, sağlıklı beslenme, fonksiyonel kullanım 
consumers perceive higher risks and regard producers less trustworthy (Grunert, 2002; Fonte, 2013). It was proposed that consumers' reflexivity is connected to, among other things, the higher level of consumer distrust in food and marketers' nutritional claims (Hansen et al. 2011; Kjaernes and Torjusen, 2012). Reflexive consumption defines how modern consumers, as constituent subjects and reflexive agents in the marketplace, construct a meaningful and coherent sense of identity (Beckett and Nayak, 2008; Falguera et al., 2012) though reflexive (re)interpretation of knowledge that is, in fact, open to revision (Giddens, 1991). Despite the attempts of the producers to put faith in hygienists, retailers, and food scientists, distrusting consumers reflexively scrutinized and replaced that sense of faith with fear and anxiety (Spaargaren et al., 2012).

Consumer anxieties on food are shaped and provoked via news in mass media concerning farm crises, food scares and scandals such as the mad cow disease and bird flu (Jackson, 2010). For instance, genetically modified foods and swine flu were two cases that had created immense controversy in Turkey; discussions in the mass media and negative word-of-mouth communications have led to immense fear and anxiety among consumer (Dedeoglu and Ventura, 2012, 2017).

Anxiety, a negative feeling triggered by the potentially harmful future events, has an obviously negative impact on well-being of consumers. Consumer anxieties shaped around food and healthy nutrition has given rise to a quest for natural and minimally-processed food that improves health (Hansen et al. 2011). Health, defined by WHO (World Health Organization) as a state of complete physical, mental and social well-being, is becoming an increasingly important personal and societal value and a motivation for the consumption of both organic and functional foods (Goetzke et al., 2014). In addition to other types of well-being, food well-being was also proposed in the literature: Block et al. (2011) defined it as a positive psychological, physical, emotional, and social relationship with food at individual and social levels.

$21^{\text {st }}$ century witnessed the rise of social media that has enabled collaborative content development and sharing, interactivity, mobile messaging, social networking services (Korda and Itani, 2013). Social media has become a part of consumers' daily lives. Functional use of social media can help consumers pursue a healthy lifestyle, cope with anxiety adaptively and achieve a certain level of well-being. Yet, next to serving as a motivator, dysfunctional use of social me- dia can pose a threat to consumers' self-preservation goal, cause anxiety and deteriorate well-being.

Both consumer anxiety and well-being are analyzed in many contexts, yet, to our best knowledge, there are insufficient number of scholarly studies that analyze the influence of shared social media content about healthy nutrition on both consumer anxiety and well-being. Moreover, although there are published statistical researches, such as RSPH (2017), that measure consumer anxiety and other emotions, in addition to studies that focus on various psychopathology, including depression, stress, social pain (Thomée et al. 2007; Kross et al., 2013; Bhagat, 2015; Woods and Scott, 2016; Elhai et al., 2017), there still remains a need to research the possible influence of related social media content on consumer anxiety and well-being, by considering all the dimensions of both constructs. Understanding how user-generated social media content about healthy nutrition influences consumers' consumer anxiety and well-being by shedding a light on both constructs can help developing new theoretical explanations of functional or dysfunctional use of social media content and its consequences. Furthermore, understanding the impact of dis/functional use of social media use on consumer emotions can help public policy makers in their effort to develop a public policy to promote functional use of social media that may have positive impact on consumer well-being.

\section{CONSUMER ANXIETY}

Consumers today live in an era of anxiety. Jackson (2010) argued that it has become a normal, everyday condition; modern consumers are said to be living in a state of constant anxiety:'a time of fears'. Anxiety is an unpleasant emotional state, characterized by tension, apprehension, and worry, and occurs in response as a threat to a self-preservation goal (Arkin and Ruck, 2007). Anxiety arises in such situations where the person is uncertain about potentially harmful outcomes of a future event, lacks self-efficacy in altering the course of events and, thus, perceives high threat (Chiou and Wan, 2006). Lee et al., (2011) proposed that being driven by fear, anxious consumers try to avoid risks of facing uncertain outcomes more so than other negative emotions such as depression, sadness or anger. Anxiety is also defined as feelings of worry, nervousness or unease; whereas depression is defined as feeling extremely low and unhappy (RSPH, 2017). Luce et al. (2001) reflected that it might prompt a goal of uncertainty reduction or risk avoidance because 
anxiety frequently involves uncertainty and lack of control. Consumer anxiety arises from a sense of threat in the context of consumption.

In the literature, anxiety was measured using various scales. Liebowitz introduced the Liebowitz Social Anxiety Scale (Liebowitz, 1987) that operationalized anxiety in fear, avoidance and social avoidance dimensions. Lovibond and Lovibond (1995) introduced the Depression Anxiety Stress Scales (DASS) that measured anxiety, next to two other negative emotional states of depression and tension/stress, by focusing on autonomic arousal, skeletal muscle effects, situational anxiety, and subjective experience of anxious affect. In their study, Scholten et al. (2017) tested the cross-cultural applicability of the DASS across four countries and found meaningfully comparable results; accordingly, for instance, Russia was the country with highest level of anxiety. Alkis et al. (2017) studied and analyzed college students' social anxiety on social media platforms. Being driven by the definition of social anxiety as the feelings of discomfort and nervousness during interaction with others in a social setting (Hartman, 1986), they distinguished four dimensions of social anxiety (shared content anxiety, privacy concern anxiety, interaction anxiety, and self-evaluation anxiety) and proposed the Social Anxiety Scale for Social Media Users. Shared content anxiety derives from sharing of content in social media by individuals themselves or by others related to them (Alkis et al., 2017). Privacy concern of social media users also triggers social anxiety (Liu, Ang, and Lwin, 2013). Privacy concern anxiety derives from the possibility of disclosing personal information on social media (Alkis et al., 2017). Individuals with a high privacy avoid sharing their personal information online (Liu et al., 2013). While interaction anxiety is defined a type of social anxiety that is felt during interaction with others, especially with the ones that are just met, on social media, self-evaluation anxiety is defined to include apprehension and fear of being judged by others (Mattick and Clarke, 1998; Alkis et al., 2017).

Consumer anxiety has been studied in the literature by analyzing the antecedent variables, such as individual choices that increases perceptions of uncertainty and risks (Locander and Hermann, 1979), impulse buying (Gardner and Rook, 1988; Aadel et al. 2016), exposure to fear appeals (Sego and Stout 1994), consumers' familiarity obtained from ongoing usage and past experience (Kuhlmeier and Knight, 2005), perception of self-efficacy (Meuter et al. 2003; Gelbrich and Sattler, 2014), potential negative evaluations from others (Alkis et al. 2017), the degree of awareness of and sensitivity to the reactions of others to one's own behavior (Piamphongsant and Mandhachitara, 2008), service or website quality and trust (Hwang and Kim, 2007; Yao and Liao, 2011). Consumer anxiety is a significant determinant of behavioral intention, i.e. intention to purchase and use (Meuter et al., 2003; Gelbrich and Sattler, 2014), consumer avoidance behavior (Lee et al., 2011) such as procrastination (Ferrari et al. 1995; Blichfeldt et al., 2015) and escapism (Darrat et al. 2016), post-purchase dissonance (Sweeney et al. 2000; Keng and Liao, 2013) and even compulsive buying (Valence et al., 1988), customer dissatisfaction (Thomson and Johnson, 2002) and disloyalty (Delacroix and Guillard, 2016).

\section{CONSUMER WELL-BEING}

There is a growing demand towards products and foods with natural ingredients and minimal processing (McGill, 2009). Falguera et al. (2012) stated that motivations underlying consumption is not only the basic biological needs, but a need to express a sense of self and improve psychological well-being. Well-being is a broad and holistic concept that signifies a state of happiness and relates to a subjective evaluation of a person's life on many dimensions, such as social, physical, emotional, spiritual, intellectual (Suranyi-Unger, 1981; McMahon, Williams and Tapsell, 2010; Ares et al., 2015). Discussions focused on some hallmarks of well-being: it is multidimensional and subjective and it relies on a balance between cognitive and affective dimensions next to positive and negative emotions (e.g. Diener, 1984; Adams et al., 1997). Diener et al. (1999) and Diener (2000) identified main components of subjective well-being as emotional responses (including positive and negative emotions), domain-specific satisfactions, and global judgments of life satisfaction.

Suranyi-Unger (1981) identified hedonic, commodity-specific, and income-specific approaches to the definition and measurement of consumer wellbeing. While hedonic approach is built upon on the theory of social welfare and concepts of preference, choice, satisfaction, and utility and utilizes subjective measures of satisfaction, commodity-specific approach relies on the input of goods and services that are used to meet a predesignated minimum level of well-being that is measured with possession of commodities. Income-specific approach is based on expression 
of well-being levels as an income-level requirement (Suranyi-Unger, 1981).

Different approaches operationalized the well-being construct varyingly. Miscellaneous operationalization indicates that it is a multidimensional construct and relates to every domain of human life. While Veenhoven (2000) discussed four dimensions of well-being which are livability of the environment (good living conditions), utility of life (the extent to which higher values are achieved), life ability of the person (how well a person is prepared to cope with life) and appreciation of life (related to subjective well-being), Hettler (1984) defined well-being in six interdependent dimensions; physical, intellectual, social, emotional, occupational and spiritual well-being. Adding societal level next to individual level of assessments, Block et al. (2011) distinguished psychological, physical, emotional, and social dimensions. King et al. (2015) analyzed well-being using emotional, intellectual, physical, social, and spiritual dimension; they found that physical dimension had the highest correlation with well-being. Physical well-being relates to assessments of physical activity, nutrition, health and vitality. While spiritual well-being involves perception of the meaning and purpose of one's life, emotional and psychological dimension involves the awareness, control and acceptance of feelings such as leisure, happiness, calm, quietness, and joy (Goetzke et al., 2014; Meiselman, 2016). Social well-being relates interactions to others and is affected by having the support of friends or family. Intellectual well-being relates to mental and intellectual activity and performance (Ares et al. 2015).

Using a different conceptualization, Schuster et al. (2004) discussed that health is a multidimensional construct that includes physical, psychological, social, and spiritual dimensions; and that well-being is a higher order construct which integrates all these dimensions of health.

Identifications of well-being can be diverse based on various cultural and socioeconomic contexts (Diener and Suh, 2000). For instance, in the domain of nutrition, several socioeconomic factors, such as culture, price, availability, convenience, personal preferences and environmental, social or health concerns (Falguera et al., 2012), can influence how consumers define their well-being. Ares et al. (2015) noted that average income level and self-evaluations of people as being better than others can account for cross-cultural differences.

\section{SOCIAL MEDIA: A MAJOR SOURCE OF CONSUMER WELL-BEING OR ANXIETY?}

Social media, a group of Internet-based applications that build on Web 2.0 that allow the creation and interactive exchange of user-generated content and participation in social networking (Kaplan and Haenlein, 2010), has become a part of consumers' daily lives. It has not only been as a new communication medium, it also influences users' lifestyles by altering the way people socialize, communicate and relate to each other. It allows access to information anytime and anywhere and transfers information easily. Social media affects consumers' consumption patterns and self-representation.

The uses and gratifications theory tries to explain how consumers who motivated by social and psychological needs use the media, in the present case social media platforms, and seek gratifications (Raacke and Bonds-Raacke, 2008; Koc and Gulyagci 2013). As regards to consumption habits, functional use of social media may provide consumers tools for self-expression (Belk 2013), pursuing a socially-connected and healthy lifestyle, increasing their well-being and obtaining gratification.

Social media provides the opportunity for users to control how they express and present themselves to their followers (Zhao, Grasmuck and Martin, 2008). Self-presentation can be defined as complex intraself negotiations to project a desired impression (Jensen Schau and Gilly, 2003). Social media serves as a tool of self-expression (Belk, 2013); using their social media accounts, users represent better or the best version of themselves and construct a digital self. Users can present the version of themselves that they hope to be, rather than what they actually are; thus, this could affect the content they post and the accounts that they follow that provide information about recipes and exercises (Vaterlaus et al., 2015).

In their seminal article, Price and Arnould (2003) asserted that through 'authenticating acts' consumers mark differences between self and others and to engage in acts redolent of personal style. Furthermore through 'authoritative performances' (Price and Arnould, 2003), they also express their shared participation, create a unity between themselves and community and gain individual legitimacy. Consumers employ these practices to create a narrative sense of self. Social media users' acts of creating, consuming and negotiating images and meanings function as authenticating acts; they mark differences. On the other hand, 
through contents they generate, they also perform so that they integrate the community. In their quest to express themselves and gain legitimacy, people strive to present better and mostly different (sometimes distorted) versions of themselves. Although users, in fact, create "cool" and hyperreal content that embrace consumer culture, they also consume these images no matter how unconnected they are to their real life experiences.

Since social media can improve young people's access to other people's experiences of health and expert health information, it may serve as a motivator for a healthy lifestyle (RSPH, 2017). Several studies revealed that young adults use the Internet as a health information source (McKinley and Wright, 2014; Vaterlaus et al., 2015). Vaterlaus et al. (2015) found that consumers exploit exercise related content on social media platforms. However they also found that it may serve as a barrier since the amount of time and effort spent online may replace the energy allocated for exercise and distract users (Vaterlaus et al., 2015).

Social media also affects food consumption habits; it serves as a platform that enables information sharing and receiving about food (Zilberman and Kaplan, 2014). Vaterlaus et al.'s (2015) findings indicate that wide range of information and recipes shared online leads to the expansion of food choices and diversification in meal plans. Besides the healthy recipes and healthy nutrition lifestyle, unhealthy food consumption content is also shared through social media (Vaterlaus et al., 2015). Therefore, social media may lead to an increase in high calorie food intake. If used functionally, social media may help them pursue a healthy lifestyle via diet and exercise so that they can present a better version of themselves and satisfy self-expressive needs.

However, dysfunctional use of social media platfor$\mathrm{ms}$, in addition to failed uses and gratifications, can trigger anxiety. Then again, experiencing anxiety during social media interactions can lead to spending more time on social networking sites (Ryan and Xenos, 2011; Koc and Gulyagci, 2013; Kross et al., 2013; Błachnio et al., 2015; Oberst et al., 2017). In other words, the more consumers involve in social media, the more they are likely to be subjected to anxiety-inducing content and vice versa. Kross et al. (2013) argued that being subjected to other consumers' "perfect" lifestyles, users may develop perceptions of social isolation rather than objective social isolation, thus develop social pain, and i.e. feel socially disconnected and isolated.
They also found that the more people interacted with other people directly, the more strongly Facebook use predicted declines in their affective well-being.

According to a current report (RSPH, 2017), compared to drugs and alcohol, social media happens to be more addictive for social media users, of which $91 \%$ of them are younger than 24 and consequently has led to $70 \%$ increase in depression and anxiety in the past 25 years. Analysis of social media platforms was made based on 14 health and well-being dimensions, such as anxiety, self-expression, body image; Instagram was found to have the most detrimental effect on young people's health and well-being among other platforms (RSPH, 2017). It can be proposed that image-focused platforms may influence self-esteem negatively, trigger feelings of inadequacy and anxiety and deteriorate well-being. Findings of other studies also revealed that dysfunctional use of social media can trigger various types of psychopathology, including anxiety, depression, stress and exacerbate existing conditions (Thomée et al. 2007; Bhagat, 2015; Woods and Scott, 2016; Elhai et al., 2017). Therefore, this study aims to analyze the influence of shared social media content about healthy nutrition on both consumer anxiety and well-being.

\section{THE RESEARCH METHODOLOGY}

The present study aims to describe the possible influence of social media content about healthy nutrition on consumer anxiety and well-being. For the aim of the study, online survey method was used. To find out how the participants feel when they see posts related to healthy nutrition on social media, a well-being scale is employed; the items used in the survey were inspired by the studies by King et al. (2015) and Ares et al. (2015). The scale included five dimensions (emotional, intellectual, social, physical and physical well-being) that are proposed to relate to the context of the study. While the emotional well-being dimension included items such as feeling happy and enthusiastic, intellectual well-being related to aspects like being focused and curious. Social well-being was measured with items such as being connected and accepted. While physical well-being referred to evaluations of, for instance, being active and resilient, spiritual well-being was measured with items, such as feelings of satisfaction and gratefulness.

The social media anxiety scale that aims to measure the level of anxiety when they come across or share posts related to healthy nutrition in social media was 
adapted from Alkis et al.'s (2017) the Social Anxiety Scale for Social Media Users that originally includes four dimensions; shared content anxiety, privacy concern anxiety, interaction anxiety, and self-evaluation anxiety. For the purpose of the study, shared content anxiety is operationalized in two dimensions; shared content anxiety induced by users' own posts and by other users' posts. Shared content anxiety induced by other users' posts is operationalized with items such as "The healthy nutrition content posted by others make me feel distressed.", whereas shared content anxiety induced by users' own posts is operationalized with items such as "I feel anxious that people find my posts about healthy nutrition awkward". Self-evaluation anxiety dimension is adapted so to refer to users' self-evaluations considering their all activities. Since privacy concern anxiety does not relate to the aim of the study, it is not included among other dimensions. Scale items that passed the requirements of confirmatory factor analysis appear in Table 3. All anxiety and well-being items were measured using Likert scale, where 1 means strongly disagree and 5 means strongly agree. Due to budgetary limitations, the data was collected via convenience sampling method.

\section{DEMOGRAPHIC AND SOCIAL MEDIA USAGE PROFILE OF THE PARTICIPANTS}

According to the report Digital 2019, there are 59.36 million active social media users in Turkey (Kemp, 2019). Considering the standard normal deviation set at $95 \%$ confidence level, $50 \%$ proportion of consumers who share online content of healthy nutrition and margin of error of 0.5 , the minimum sample size can be calculated as 384 (Sekaran and Bougie, 2016). The data was collected from a sample that consists of 406 consumers via convenience sampling. The demographic and social media usage profile of the participants appears on Table 1 . The majority of the participants consist of women (59.4\%), university graduates $(47.8 \%)$, consumers at ages between 0-24 (39.9\%). The average age of the participants is 32.82 . Among the participants, $35.7 \%$ spend between $1-2$ hours each day on social media. The most preferred social media platform is Instagram (56.4\%). While $43.6 \%$ percent of the participants share healthy nutrition content, $87.8 \%$ of them follow related content in some degree.

Table 1: The Demographic and Social Media Usage Profile of the Participants

\begin{tabular}{|c|c|c|c|c|c|}
\hline Education Level & $\mathbf{n}$ & $\%$ & Age $^{*}($ mean $=32,82 ;$ std. dev. $=13,12)$ & $\mathbf{n}$ & $\%$ \\
\hline High school & 110 & 27.1 & $0-24$ & 162 & 39.9 \\
\hline University & 194 & 47.8 & $25-34$ & 91 & 22.4 \\
\hline Master's / PhD & 102 & 25.1 & $35-44$ & 57 & 14.0 \\
\hline Total & 406 & 100 & $45-54$ & 59 & 14.5 \\
\hline Occupation & $\mathbf{n}$ & $\%$ & 55 and above & 37 & 9.1 \\
\hline White collar workers & 23 & 5.7 & Total & 406 & 100 \\
\hline Employee in private sector & 34 & 8.4 & Social Media Use & $\mathbf{n}$ & $\%$ \\
\hline Employee at public sector & 38 & 9.4 & Less than 1 hour & 68 & 16.7 \\
\hline Professions that requires expertise & 91 & 22.4 & $1-2$ hours & 145 & 35.7 \\
\hline Merchant & 24 & 5.9 & 2-3 hours & 95 & 23.4 \\
\hline Manager & 10 & 2.5 & More than 3 hours & 98 & 24.1 \\
\hline Retired & 10 & 2.5 & Total & 406 & 100 \\
\hline Housewife & 8 & 2.0 & Social Media Platform Used the Most & $\mathbf{n}$ & $\%$ \\
\hline Student & 154 & 37.9 & Instagram & 229 & 56.4 \\
\hline Unemployed & 7 & 1.7 & Facebook & 61 & 15.0 \\
\hline Other & 7 & 1.7 & Twitter & 52 & 12.8 \\
\hline Total & 406 & 100 & Linkedln & 14 & 3.4 \\
\hline Gender & $\mathbf{n}$ & $\%$ & Other & 50 & 12.3 \\
\hline Women & 241 & 59.4 & Total & 406 & 100 \\
\hline Men & 165 & 40.6 & & & \\
\hline Total & 406 & 100 & & & \\
\hline $\begin{array}{l}\text { Frequency of Posting Healthy Nutrition } \\
\text { Content }\end{array}$ & $\mathbf{n}$ & $\%$ & $\begin{array}{l}\text { Frequency of Following Healthy Nutrition } \\
\text { Posts }\end{array}$ & $\mathbf{n}$ & $\%$ \\
\hline Never & 229 & 56.4 & Never & 49 & 12.1 \\
\hline Rarely & 110 & 27.1 & Rarely & 92 & 22.7 \\
\hline Sometimes & 51 & 12.6 & Sometimes & 138 & 34.0 \\
\hline Often & 10 & 2.5 & Often & 86 & 21.2 \\
\hline Always & 6 & 1.5 & Always & 41 & 10.1 \\
\hline Total & 406 & 100 & Total & 406 & 100 \\
\hline
\end{tabular}


Participants disagree that healthy nutrition contents posted on social media platforms are convincing, reassuring, scientific or valid (Table 2 ). It is difficult to propose that participants believe and thus get highly involved in healthy nutrition contents.

Table 2: Participant's Thoughts About Believability and Scientific Validity of the Healthy Nutrition Posts

\begin{tabular}{|c|c|c|c|c|}
\hline $\begin{array}{l}\text { Item } \\
\text { “Healthy nut } \\
\text { contents on } \\
\text { media platfo } \\
\text {..." }\end{array}$ & $\mathbf{N}$ & Mean & Std. dev. & $\mathbf{t}$ \\
\hline Convincing & 406 & 2.81 & 0.946 & $-4.040^{*}$ \\
\hline Reassuring & 406 & 2.76 & 0.932 & $-5.165^{*}$ \\
\hline Scientific & 406 & 2.56 & 0.919 & $-9.718^{*}$ \\
\hline Valid & 406 & 2.72 & 0.930 & $-6.086^{*}$ \\
\hline
\end{tabular}

\section{FINDINGS ABOUT ANXIETY TRIGGERED BY HEALTHY NUTRITION POSTS}

The items used to measure social anxiety were adapted from the Social Anxiety Scale proposed by Alkis et al. (2017). By healthy nutrition content, it is referred to the user-generated online content about, for instance, healthy ingredients and nutritional value of foods, and preparing processes of healthy foods. To verify the factor structure of the set of observed anxiety variables and facilitate testing the adaptation of the original scale, confirmatory factor analysis is conducted (Table 3). The items that provided estimates of squared multiple correlations lower than 0.5 are removed from the scale. The model fit indices (CMIN/ $\mathrm{DF}=2.903 ; \mathrm{GFI}=0.941 ; \mathrm{AGFI}=0.905 ; \mathrm{NFI}=0.952 ; \mathrm{CFI}$ $=0.968$; RMSEA $=0.069$ ) indicate a satisfactory fit of the model to the sample data. Internal consistency reliability statistics of each dimension are satisfactory.

Table 3: Confirmatory Factor Analysis of the Adapted Social Anxiety Scale For Social Media Users

\begin{tabular}{|c|c|c|c|}
\hline Factor & & $\begin{array}{l}\text { Standardized } \\
\text { Regression } \\
\text { Weights }\end{array}$ & $\begin{array}{l}\text { Critical } \\
\text { Ratio }\end{array}$ \\
\hline \multirow{3}{*}{$\begin{array}{l}\text { Shared Content } \\
\text { Anxiety Induced by } \\
\text { Posts of Users' Own }\end{array}$} & $\begin{array}{l}\text { I feel anxious that people find my posts about healthy } \\
\text { nutrition awkward. }\end{array}$ & .550 & * \\
\hline & $\begin{array}{l}\text { I am concerned by the fact that healthy nutrition contents I } \\
\text { share will not be liked by others. }\end{array}$ & .695 & $12.740^{+}$ \\
\hline & $\begin{array}{l}\text { I would feel uncomfortable when my friends publicly express } \\
\text { their dislike about healthy nutrition contents I have shared. }\end{array}$ & .915 & $12.415^{+}$ \\
\hline Cronbach alpha $=0.871$ & $\begin{array}{l}\text { I am concerned about being judged about my shared healthy } \\
\text { nutrition contents by my friends in the presence of others. }\end{array}$ & .971 & $12.560^{+}$ \\
\hline \multirow{3}{*}{$\begin{array}{l}\text { Shared Content } \\
\text { Anxiety Induced by } \\
\text { Other Users' Posts }\end{array}$} & Healthy nutrition posts make me feel anxious. & .833 & * \\
\hline & $\begin{array}{l}\text { The healthy nutrition content posted by others make me feel } \\
\text { distressed. }\end{array}$ & .881 & $15.671^{+}$ \\
\hline & $\begin{array}{l}\text { I find it awkward that the people I follow post healthy nutrition } \\
\text { content on social media. }\end{array}$ & .539 & $10.675^{+}$ \\
\hline \multicolumn{4}{|c|}{ 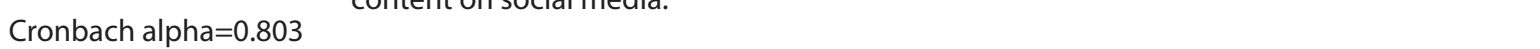 } \\
\hline \multirow[t]{3}{*}{ Interaction Anxiety } & I feel anxious when talking with users I have just met. & .849 & * \\
\hline & I feel nervous when I talk with users I do not know very well. & .949 & $22.779^{+}$ \\
\hline & I am afraid of interacting with other users. & .727 & $15.235^{+}$ \\
\hline Cronbach alpha $=0.885$ & I feel nervous when I have to talk with other users about myself & .698 & $16.032^{+}$ \\
\hline \multirow[t]{2}{*}{$\begin{array}{l}\text { Self-Evaluation } \\
\text { Anxiety }\end{array}$} & $\begin{array}{l}\text { I feel anxious about making a negative impression on other } \\
\text { users. }\end{array}$ & .877 & * \\
\hline & I am concerned about other users thinking poorly of me. & .916 & $24.555^{+}$ \\
\hline Cronbach alpha $=0.903$ & $\begin{array}{l}\text { I feel anxious about not being able to meet other users' } \\
\text { expectations. }\end{array}$ & .816 & $20.891^{+}$ \\
\hline
\end{tabular}

* The unstandardized regression weight of the first variable of each component factor is fixed at 1, thus the critical ratio is not available. $+p=0.001$ 
One sample t-tests were conducted in order to discover the social anxiety levels of participants (Table 4). The findings reveal that that the participants do not feel anxious for sharing healthy nutrition content on social media. They do not also feel anxious for people not liking or judging their health-related posts and for showing their negative reaction in front of others. Thus, anxiety due to the content shared by participants themselves is found to be low. Healthy nutrition contents that are shared by other users do not cause much anxiety over participants, as well. Low level of interaction anxiety indicate that the participants do not feel so nervous when talking to the people they just met on social media and they do not hesitate interacting with people on social media. Low level of self-evaluation anxiety indicates that participants do not feel so anxious in terms of self-evaluation because of what other people think about them on social media platforms.

Despite the finding that the level of social anxiety felt by the participants is not so much influenced by the contents of healthy nutrition posts shared by themselves or others, self-evaluations or how they interact, there are some differences in the anxiety levels between frequent users of different platforms. Frequent Instagram and Twitter users' self-evaluation anxiety $(\mathrm{F}=2.401 \mathrm{sd}: 4 / 401 \quad p=.049)$ and interaction anxiety ( $\mathrm{F}=2.400 \mathrm{sd}: 4 / 401 p=.036)$ due to the healthy nutrition posts is higher compared to Facebook, Linkedln and other platforms users, in this particular order. Healthy nutrition posts on Instagram and Twitter influence frequent users' anxiety felt during social interactions or due to being negatively evaluated by other people during interactions more compared to others posts on other platforms.

The findings reveal that the more participants share healthy nutrition contents on social media the more they follow content shared by other (Pearson chi-square $=73 \mathrm{df}: 9 p=.000$ ). In other words, social media users who share healthy nutrition contents are the ones who actually follow related contents. The more participants share healthy nutrition contents the less they develop anxiety due to the content shared by others $(\mathrm{F}=3.467$ df:4/401 $p=.000$ ), i.e. they feel less threatened by the content shared by others. Furthermore, the more they follow related content, the more they develop self-evaluation anxiety ( $\mathrm{F}=6.964 \mathrm{df}: 4 / 401 p=.000)$ and the less they develop anxiety induced by the content shared by others ( $\mathrm{F}=3.878 \mathrm{df}: 4 / 401 p=.004)$. The more they follow related content on social media, the less they feel threatened by the content shared by others, however, the more they negatively evaluate themselves because of what other people might think about them.

Table 4: One Sample T-Test Results For Anxiety Scale Items

\begin{tabular}{|c|c|c|c|c|}
\hline Item & $\mathbf{N}$ & Mean & Std. dev. & $\mathbf{t}$ \\
\hline \multicolumn{5}{|l|}{ Content Anxiety -Shared By Participants } \\
\hline I feel anxious that people find my posts about healthy nutrition awkward. & 406 & 2.25 & 1.21 & $-12.50^{*}$ \\
\hline I am concerned by the fact that healthy nutrition contents I share will not be liked by others. & 406 & 2.07 & 1.08 & $-17.22^{*}$ \\
\hline $\begin{array}{l}\text { I would feel uncomfortable when my friends publicly express their dislike about healthy } \\
\text { nutrition contents I have shared. }\end{array}$ & 406 & 2.38 & 1.26 & $-9.87^{*}$ \\
\hline $\begin{array}{l}\text { I am concerned about being judged about my shared healthy nutrition contents by my friends } \\
\text { in the presence of others. }\end{array}$ & 406 & 2.25 & 1.19 & $-12.65^{*}$ \\
\hline \multicolumn{5}{|l|}{ Content Anxiety - Shared By Others } \\
\hline Healthy nutrition posts make me feel anxious. & 406 & 1.82 & .99 & $-23.95^{*}$ \\
\hline The healthy nutrition content posted by others make me feel distressed. & 406 & 1.76 & .96 & $-25.95^{*}$ \\
\hline I find it awkward that the people I follow post healthy nutrition content on social media. & 406 & 1.99 & 1.14 & $-17.80^{*}$ \\
\hline \multicolumn{5}{|l|}{ Interaction Anxiety } \\
\hline I feel anxious when talking with users I have just met. & 406 & 2.64 & 1.27 & $-5.77^{*}$ \\
\hline I feel nervous when I talk with users I do not know very well. & 406 & 2.70 & 1.26 & $-4.80^{*}$ \\
\hline I am afraid of interacting with other users. & 406 & 2.07 & 1.01 & $-18.42^{*}$ \\
\hline I feel nervous when I have to talk with other users about myself & 406 & 2.48 & 1.21 & $-8.71 *$ \\
\hline \multicolumn{5}{|l|}{ Self-evaluation Anxiety } \\
\hline I feel anxious about making a negative impression on other users*. & 406 & 2.78 & 1.30 & $-3.36^{*}$ \\
\hline I am concerned about other users thinking poorly of me. & 406 & 2.72 & 1.28 & $-4.35^{*}$ \\
\hline I feel anxious about not being able to meet other users' expectations. & 406 & 2.54 & 1.26 & $-7.31 *$ \\
\hline
\end{tabular}

${ }^{*} p<0.01$ 
The findings reveal positive correlations between self-evaluation anxiety and finding healthy nutrition posts convincing ( $r=0.217 \mathrm{df}: 406 p=.000)$, reassuring $(r=0.237 \mathrm{df}: 406 p=.000)$, scientific $(r=0.231 \mathrm{df}: 406$ $p=.000)$ and valid ( $r=0.239 \mathrm{df}: 406 p=.000)$. The more participants believe that the posts are convincing, reassuring, scientific and valid, the more they feel anxious in terms of evaluating oneself because of what other people think about them on social media platforms. However, there are no significant correlations between other anxiety dimensions and evaluations of posts in terms of believability and scientific validity of its content. Thus, no matter how they evaluate the content of healthy nutrition posts, both their shared content anxiety and interaction anxiety do not change; i.e. whether they are scientific and reassuring or not, shared content on healthy nutrition and interaction with others do not make them feel so anxious. The relationships do not change irrespective of the participants' tendency to share and/or follow related contents. Thus, the involvement level of the participants does not moderate the relationship between anxiety dimensions and evaluations of posts in terms of believability and scientific validity of its content. It means that no matter how involved they are, the more they evaluate the content in terms of believability and scientific validity, the more self-evaluation anxiety they develop, but they do not feel more anxious due to the shared content or interaction about the content even when they scrutinize it. This finding indicates that, being involved or not, participants just apprehend the healthy nutrition content without much deliberation, and do not feel so threatened.

Despite the fact that participants do not truly perceive healthy nutrition content as threats and feel so anxious, for instance, females and older consumers are expected to feel more threatened as health and nutrition concerns may become more important for women and as consumers get older. Surprisingly, no significant relationship was found between demographic variables and consumer anxiety dimensions. The methodological limitations of the present study, such as relying on a sample that is chosen by convenience sampling and, thus, may not represent of the entire population, may account for the lack of expected relationships. Then again, the findings of a study (Aktan, 2018) about social anxiety of university students in Turkey that revealed only minor relationship between gender and consumer anxiety should also be considered. The motives and reasons behind this can also further be investigated with qualitative techniques, such as projective techniques and in-depth interviews.

\section{FINDINGS ABOUT WELL-BEING AND HEALTHY NUTRITION POSTS}

The items used to measure well-being were adapted from the The WellSense Profile proposed by King et al. (2015) and the study of Ares et al. (2015). To verify the factor structure of the set of observed well-being variables and facilitate testing the adaptation of the original scales, confirmatory factor analysis is conducted (Table 5). The items that provided estimates of squared multiple correlations lower than 0.5 are removed from the scale. The final model fit indices (CMIN/DF=2.524; $\mathrm{GFI}=0.931 ; \mathrm{AGFI}=0.892 ; \mathrm{NFI}=0.962 ; \mathrm{CFI}=0.976 ; \mathrm{RMSEA}$ $=0.061)$ indicate a satisfactory fit of the model to the sample data. The dimensions underlying the adapted well-being scale include emotional, intellectual, social, physical and spiritual well-being. Internal consistency reliability statistics of each dimension are satisfactory.

One sample t-tests were used to discover the possible effects of healthy nutrition posts on social media on participants' well-being (Table 6). Participants were asked how healthy nutrition content on social media makes them feel in five dimensions of well-being (emotional, intellectual, social, physical and spiritual). The findings reveal that participants had positive emotions, such as happiness, calmness and enthusiasm, when confronted to healthy nutrition posts on social media. However, they are not certain whether contents make them feel joyful or not. Healthy nutrition posts influences participants' intellectual well-being positively. They feel curious, focused and intellectually stimulated when they encounter healthy nutrition posts. On the other hand, participants' social well-being is negatively influenced by the related content; they felt less connected, sociable and accepted. Moreover, participants are not certain whether those contents influenced their physical or spiritual well-being. These findings reveal that healthy nutrition posts influences emotional and intellectual well-being positively and social well-being negatively. 
Table 5: Confirmatory Factor Analysis of the Adapted Well-Being Scale

\begin{tabular}{|c|c|c|c|}
\hline Factor & & Standardized Regression Weights & Critical Ratio \\
\hline \multirow[t]{2}{*}{ Emotional Well-being } & Happy & .842 & * \\
\hline & Calm & .671 & $16.136^{+}$ \\
\hline \multirow{2}{*}{ Cronbach alpha $=0.880$} & Enthusiastic & .818 & $19.932^{+}$ \\
\hline & Joyful & .878 & $22.231^{+}$ \\
\hline Intellectual Well-being & Stimulated & .824 & * \\
\hline \multirow{2}{*}{ Cronbach alpha $=0.883$} & Focused & .884 & $21.150^{+}$ \\
\hline & Curious & .823 & $19.193^{+}$ \\
\hline Social Well-being & Connected & .856 & * \\
\hline \multirow{2}{*}{ Cronbach alpha $=0.865$} & Sociable & .909 & $23.251^{+}$ \\
\hline & Accepted & .733 & $17.027^{+}$ \\
\hline \multirow[t]{3}{*}{ Physical Well-being } & Energetic & .909 & * \\
\hline & Active & .946 & $34.134^{+}$ \\
\hline & Invigorated & .959 & $35.700^{+}$ \\
\hline \multirow[t]{2}{*}{ Cronbach alpha $=0.874$} & Healthy & .804 & $22.687^{++}$ \\
\hline & Resilient & .821 & 23.676 \\
\hline \multirow{2}{*}{$\begin{array}{l}\text { Spiritual Well-being } \\
\text { Cronbach alpha }=0.886\end{array}$} & Satisfied & .910 & * \\
\hline & Grateful & .871 & $24.887^{+}$ \\
\hline
\end{tabular}

* The unstandardized regression weight of the first variable of each component factor is fixed at 1 , thus the critical ratio is not available. ${ }^{+} p=0.001$

Table 6: One Sample T-Test Results For Well-Being Scale Items

\begin{tabular}{|c|c|c|c|c|c|}
\hline \multicolumn{2}{|c|}{$\begin{array}{l}\text { Item } \\
\text { "When I see healthy } \\
\text { nutrition content on social } \\
\text { media I feel.." }\end{array}$} & $\mathbf{N}$ & Mean & $\begin{array}{l}\text { Std. } \\
\text { dev. }\end{array}$ & $\mathbf{t}$ \\
\hline \multirow{4}{*}{$\begin{array}{l}\text { Emotional } \\
\text { Well-Being }\end{array}$} & Happy & 406 & 3.24 & 1.17 & $4.17^{*}$ \\
\hline & Calm & 406 & 3.24 & 1.13 & $4.32 *$ \\
\hline & Enthusiastic & 406 & 3.41 & 1.22 & $6.85^{*}$ \\
\hline & Joyful & 406 & 3.03 & 1.23 & .62 \\
\hline \multirow{3}{*}{$\begin{array}{l}\text { Intellectual } \\
\text { Well-Being }\end{array}$} & Stimulated & 406 & 3.43 & 1.17 & $7.42^{*}$ \\
\hline & Focused & 406 & 3.27 & 1.18 & $4.58^{*}$ \\
\hline & Curious & 406 & 3.63 & 1.21 & $10.42^{*}$ \\
\hline \multirow{3}{*}{$\begin{array}{l}\text { Social Well- } \\
\text { Being }\end{array}$} & Connected & 406 & 2.73 & 1.10 & $-4.95^{*}$ \\
\hline & Sociable & 406 & 2.84 & 1.17 & $-2.80^{*}$ \\
\hline & Accepted & 406 & 2.54 & 1.19 & $-7.82^{*}$ \\
\hline \multirow{5}{*}{$\begin{array}{l}\text { Physical } \\
\text { Well-Being }\end{array}$} & Energetic & 406 & 3.03 & 1.18 & .59 \\
\hline & Active & 406 & 3.02 & 1.18 & .30 \\
\hline & Invigorated & 406 & 3.03 & 1.19 & .46 \\
\hline & Healthy & 406 & 3.07 & 1.19 & 1.13 \\
\hline & Resilient & 406 & 3.00 & 1.16 & .09 \\
\hline \multirow{2}{*}{$\begin{array}{l}\text { Spiritual } \\
\text { Well-Being }\end{array}$} & Satisfied & 406 & 2.99 & 1.15 & -.17 \\
\hline & Grateful & 406 & 3.09 & 1.18 & 1.52 \\
\hline
\end{tabular}

Participants' well-being is influenced by the healthy nutrition posts to a certain degree. Moreover, the findings reveal some differences in terms of the level of influence between frequent users of different platforms. Frequent Instagram and Linkedln users' emotional ( $\mathrm{F}=3.464 \mathrm{sd}: 4 / 401 p=.008)$, intellectual $(\mathrm{F}=2.599 \mathrm{sd}: 4 / 401 p=.036)$, social $(\mathrm{F}=3.663 \mathrm{sd}: 4 / 401$ $p=.006)$ and physical well-being $(\mathrm{F}=2.688 \mathrm{sd}: 4 / 401$ $p=.031$ ) are more positively influenced by the healthy nutrition posts compared to Facebook, Twitter and other platforms users, in this particular order. For instance frequent Instagram and Linkedln users feel happier $(\mathrm{F}=2.946 \mathrm{sd}: 4 / 401 p=.020)$, calmer $(\mathrm{F}=2.855$ $\mathrm{sd}: 4 / 401 p=.023)$, more willing ( $\mathrm{F}=3.184 \mathrm{sd}: 4 / 401$ $p=.014)$, more joyful ( $F=2.569 \mathrm{sd}: 4 / 401 p=.038)$, more curious ( $F=2.693 \mathrm{sd}: 4 / 401 p=.031)$, closer to people $(\mathrm{F}=3.296 \mathrm{sd}: 4 / 401 p=.011)$, more social $(\mathrm{F}=3.555$ $\mathrm{sd}: 4 / 401 p=.007)$, more energetic $(\mathrm{F}=3.101 \mathrm{sd}: 4 / 401$ $p=.016)$ and more youthful ( $F=2.389 \mathrm{sd}: 4 / 401 p=.050)$ compared to Facebook, Twitter and other platforms users, respectively. All users are equally indecisive in whether their spiritual well-being influenced by the healthy nutrition posts.

The findings reveal that the more the participants believe that healthy nutrition posts are convincing, reassuring, scientific and valid, the more their emotional, intellectual, social, physical and spiritual well-being increase (Table 7). 
Table 7: Pearson Correlations Between Well-Being Dimensions and Participants'Evaluation of Contents of Healthy Nutrition Post

\begin{tabular}{lccrrr}
\hline & Posts Are... & Convincing & Reassuring & Scientific & Valid \\
\hline Emotional Well-being & $0.504^{*}$ & $0.482^{*}$ & $0.395^{*}$ & $0.448^{*}$ \\
\hline Intellectual Well-being & $0.499^{*}$ & $0.480^{*}$ & $0.401^{*}$ & $0.460^{*}$ \\
\hline Social Well-being & $0.438^{*}$ & $0.433^{*}$ & $0.360^{*}$ & $0.401^{*}$ \\
\hline Physical Well-being & $0.520^{*}$ & $0.513^{*}$ & $0.420^{*}$ & $0.476^{*}$ \\
\hline Spiritual Well-being & $0.540^{*}$ & $0.548^{*}$ & $0.458^{*}$ & $0.510^{*}$ \\
\hline
\end{tabular}

${ }^{*} p<0.01$ and $N=406$

Although not being significantly related to dimensions of social anxiety, some demographic variables significantly related to well-being dimensions. Women significantly experienced greater emotional ( $\mathrm{t}=3.670 \mathrm{df}: 404 p=.000$ ), intellectual ( $\mathrm{t}=4.863 \mathrm{df}: 331.7$ $p=.000)$, physical ( $\mathrm{t}=3.129 \mathrm{df}: 327.3 p=.002)$ and spiritual well-being ( $\mathrm{t}=3.358 \mathrm{df}: 324.7 p=.001$ ) compared to men. Furthermore, there are differences between participants' level of emotional ( $F=2.761 \mathrm{df}: 9 / 396$ $p=.004)$, intellectual ( $F=2.355 \mathrm{df}: 9 / 396 p=.013)$, physical ( $\mathrm{F}=2.724 \mathrm{df}: 9 / 396 p=.004)$ and spiritual well-beings ( $F=2.606 \mathrm{df}: 9 / 396 p=.006$ ) based on their household income; as their income increases, their evaluations of well-being decrease. There are no significant relationship between age, marital status and education and well-being dimensions. It can be suggested that women, as consumers who are expected to have health and nutrition concerns, and participants with low/ middle income functionally utilized healthy nutrition content better than the others. Free online content on healthy nutrition may be seen as a source to enhance well-being by less affluent consumers.

\section{DISCUSSION AND CONCLUSION}

The present study aims to describe the possible influence of social media content on healthy nutrition that may cause anxiety or increase consumers' well-being and fill a gap in the literature for studies that scrutinize the influence of shared social media content about healthy nutrition on both consumer anxiety and well-being. Social media, which affects consumers' consumption patterns and self-representation, can be a major source of consumer well-being or anxiety. Functional use of social media may provide consumers tools for self-expression, pursuing a socially-connected and healthy lifestyle, increasing their well-being and obtaining gratification. However, dysfunctional use of social media platforms, in addition to failed uses and gratifications, can trigger anxiety, next to various types of psychopathology.
The findings demonstrate that the participants do not feel so anxious due to the healthy nutrition content shared by other users or themselves, due to interactions on the topic or due to the self-evaluations about what other people think about them on social media platforms. Considering that approximately $44 \%$ of the participants share and $88 \%$ follow healthy nutrition content in some degree, a reason why they do not feel threatened by these content and sharing activity may be that the content may be used by the participants functionally, i.e. in an authenticating action (Price and Arnould, 2003) that help them pursue a socially-connected and healthy lifestyle, express themselves, gain legitimacy, and obtain gratification, as suggested by, for instance, Belk (2013), McKinley and Wright (2014), Vaterlaus et al. (2015). Then again, it is important to recognize that it is also possible they may have shared the content with a critical and skeptical approach. On the other hand, other findings also indicate that the involvement level of the participants does not moderate the relationship between anxiety dimensions and evaluations of posts in terms of believability and scientific validity of its content. It means that no matter how involved they are, the more they evaluate the content in terms of believability and scientific validity, the more self-evaluation anxiety they develop, but they do not feel more anxious due to the shared content or interaction about the content even when they scrutinize it. Thus, being involved or not, participants just apprehend the healthy nutrition content without much deliberation, and do not feel so threatened. Since the findings of the present study cannot point to a particular reason, there is a need for exploratory studies that aims to understand motives underlying their behavior.

The findings about consumer anxiety also indicate that the more participants share healthy nutrition contents, the less they feel threatened by the content that are even shared by others. In their study about the influence of social media interactions on consumer- 
brand relationships, Hudson et al., (2016) found that low frequency interaction might lead to anxiety and illustrated an anticipation of reduced uncertainty and risk due to the reason that social media interaction can increase the knowledge and understanding between the consumer and the brand. As consumers begin sharing more content, the perceptions of threats and risk can deteriorate. Furthermore, the more they follow related content on social media, the less they feel threatened by the content shared by others, yet, the more they negatively evaluate themselves because of what other people might think about them. In other words, when consumers share related content, they do not perceive threatened by the other consumers' post, however following related content make them feel anxious in terms of self-evaluation. Moreover, healthy nutrition posts on Instagram and Twitter influence frequent users' self-evaluation and interaction anxiety more compared to others posts on other platforms; users feel more worried, nervous or uneasy felt during social interactions or due to being negatively evaluated by other people during interactions more compared to others posts on other platforms. This finding also needs further exploration via future studies; while Instagram is an image-based platform, Twitter is a text-based platform. Thus, the level of consumer anxiety in the context of healthy nutrition may be influenced by images, yet convincing tweets and debates may also be affective. Considering the low level of anxiety felt by the participants, the nature and intensity of the influence of each social media platform posts need further investigation.

The findings about consumer well-being reveal that participants had positive emotions, such as happiness, when confronted to healthy nutrition posts. The posts influenced participants' intellectual well-being positively; they feel curious, focused and intellectually stimulated when they encounter them. However, their social well-being is negatively influenced by the related content; they felt less connected, sociable and accepted. These findings reveal that healthy nutrition posts influence emotional and intellectual well-being positively and social well-being negatively, yet, they are ineffective in terms of physical or spiritual well-being. Furthermore, it is found that the more the participants believe that posts are convincing, reassuring, scientific and valid, the more their emotional, intellectual, social, physical and spiritual well-being increase. It is also found that frequent Instagram and Linkedln users' emotional, intellectual, social and physical well-being are more positively influenced by the healthy nutrition posts compared to Facebook, Twitter and other platforms users. Then again, considering different nature of these platforms, the mechanism of these platforms' influence needs further investigation.

Although not being significantly related to dimensions of social anxiety, some demographic variables are significantly related to well-being dimensions. Women significantly experienced greater emotional, intellectual, physical and spiritual well-being compared to men. Furthermore, as their income increases, their emotional, intellectual, physical and spiritual well-beings increase. It can be suggested that women and participants with low/middle income functionally used healthy nutrition content more functionally than the others.

Having a descriptive purpose, the present study demonstrates that consumers do not feel so threatened by the shared healthy nutrition contents and may have used these contents functionally for gratifications resulting in a slight increase of their well-being. However, considering low level consumer involvement and somehow negative perceptions of scientific validity of the content, it can be proposed that this conclusion can be premature. The results that indicate consumers' functional use of online contents about healthy nutrition can help companies in developing marketing strategies that aim to increase consumer well-being. Considering that a low level of consumer anxiety and high level of well-being may diminish the likelihood of consumer avoidance behavior, such as procrastination and escapism, incorporating online content about healthy nutrition may help marketers to improve purchase intentions and customer satisfaction. Since Instagram and Twitter users' self-evaluation and interaction anxieties are found to be higher, using the social media platforms other than these may help marketers to avoid negative returns on their investments of marketing campaigns that incorporate healthy nutrition topics. Moreover, bearing in mind that healthy nutrition posts influence emotional and intellectual well-being positively, the marketers can appeal to feelings such as happiness and try to create online healthy nutrition content that aims to increase curiosity and to stimulate customers intellectually. They also should consider creating interactive content, for instance, with the help of platform technologies and crowdsourcing that involves consumers so that they can feel more connected and accepted. Furthermore, using scientifically valid content may also help marketers get positive results. 
Fulfilling its descriptive aim, the present study's findings points to a need for further investigations of the motives underlying behaviors and emotions. Moreover, studying consumer anxiety and well-being constructs using different contexts, such as exercising, and also with improved research methodology in terms of sampling and sample size, may also facilitate obtaining more significant results and develop explanations. Future qualitative studies can help to understand the underlying motives and develop insight of the consumer experiences. Another topic of inquiry inviting future study pertains to consumers' coping mechanisms for anxiety and low-level of well-being caused by social media content. 


\section{REFERENCES}

Adams, T., Bezner, J., \& Steinhardt, M. (1997). The conceptualization and measurement of perceived wellness: Integrating balance across and within dimensions. American Journal of Health Promotion, $11(3), 208-218$.

Aktan, E. (2018). Sosyal medya ve sosyal kaygı: Sosyal medya kullanıcıları üzerine bir araştırma. Selçuk Üniversitesi İletişim Fakültesi Akademik Dergisi, 11(2), 35-53.

Alkis, Y., Kadirhan, Z., \& Sat, M. (2017). Development and validation of social anxiety scale for social media users. Computers in Human Behavior, 72, 296-303.

Ares, G., de Saldamando, L., Giménez, A., Claret, A., Cunha, L. M., Guerrero, L., ... \& Deliza, R. (2015). Consumers' associations with well-being in a food-related context: A cross-cultural study. Food Quality and Preference, 40, 304-315.

Arkin, Robert M. and Lana Ruck (2007), "Anxiety," in Encyclopedia of Social Psychology, ed. Roy F. Baumeister and Kathleen D. Vohs, Thousand Oaks, CA: Sage, 42-43.

Beckett, A., \& Nayak, A. (2008). The reflexive consumer. Marketing Theory, 8(3), 299-317.

Belk, R. W. (2013). Extended self in a digital world. Journal of Consumer Research, 40(3), 477-500.

Bhagat, S. (2015). Is Facebook a planet of lonely individuals? A review of literature. The International Journal of Indian Psychology, 3(1), 5-9.

Błachnio, A., Przepiórka, A., \& Pantic, I. (2015). Internet use, facebook intrusion, and depression: Results of a cross-sectional study. European Psychiatry, 30(6), 681-684.

Blichfeldt, B. S., Mikkelsen, M., \& Gram, M. (2015). When it stops being food: The edibility, ideology, procrastination, objectification and internalization of household food waste. Food, Culture \& Society, 18(1), 89-105.

Block, L. G., Grier, S. A., Childers, T. L., Davis, B., Ebert, J. E., Kumanyika, S., ... \& Pettigrew, S. (2011). From nutrients to nurturance: A conceptual introduction to food well-being. Journal of Public Policy \& Marketing, 30(1), 5-13.

Chiou, Wen-Bin and Chin-Sheng Wan (2006). The effects of anxiety and sadness on travelers' decisions and perceived risk: Mood management as an active process of affect-adjustment. in AP - Asia-Pacific Advances in Consumer Research, eds. Lees M.C., Davis
T. , and Gregory G., (7), 385-392, Sydney, Australia: Association for Consumer Research.

Darrat, A. A., Darrat, M. A., \& Amyx, D. (2016). How impulse buying influences compulsive buying: The central role of consumer anxiety and escapism. Journal of Retailing and Consumer Services, 31, 103-108.

Dedeoglu, A. O., \& Ventura, K. (2012). Analysis of consumer responses to health threat of genetically modified foods: A pilot study. Iktisat, Işletme ve Finans, 27(313), 35-56.

Dedeoglu, A. O., \& Ventura, K. (2017). Consumer responses to swine flu (H1N1) threat and fear arousing communications: The case of turkey. In The Customer is NOT Always Right? Marketing Orientations in a Dynamic Business World. ed. Campbell, Colin L, Springer: Cham, 249-258.

Delacroix, E., \& Guillard, V. (2016). Consumers who avoid relationships: social anxiety in commercial contexts. Journal of Consumer Behaviour, 15(4), 370-384.

Diener, E. (1984) Subjective well-being, Psychological Bulletin, 95(3), 542-575.

Diener, E., Suh, E., Lucas, R. E., \& Smith, H. L. (1999). Subjective well-being: Three decades of progress. Psychological Bulletin, 125(2), 276-302.

Diener, E. (2000). Subjective well-being: The science of happiness and a proposal for a national index. American Psychologist, 55(1), 34.

Diener, E., \& Suh, E. M. (2000). Measuring subjective well-being to compare the quality of life of cultures. Culture and subjective well-being, 3-12.

Elhai, J. D., Dvorak, R. D., Levine, J. C., \& Hall, B. J. (2017). Problematic smartphone use: A conceptual overview and systematic review of relations with anxiety and depression psychopathology. Journal of Affective Disorders, 207, 251-259.

Falguera, V., Aliguer, N., \& Falguera, M. (2012). An integrated approach to current trends in food consumption: Moving toward functional and organic products? Food Control, 26(2), 274-281.

Ferrari, J. R., Johnson, J. L., \& McCown, W. G. (1995). Procrastination and task avoidance: Theory, research, and treatment. Springer Science \& Business Media.

Fonte, M. (2013). Food consumption as social practice: Solidarity purchasing groups in Rome, Italy. Journal of Rural Studies, 32, 230-239.

Gardner, M. P., \& Rook, D. W. (1988). Effects of impulse purchases on consumers' affective states. in NA - 
Advances in Consumer Research, ed. Houston M.J., (15), 127-130. Provo, UT : Association for Consumer Research.

Gelbrich, K., \& Sattler, B. (2014). Anxiety, crowding, and time pressure in public self-service technology acceptance. Journal of Services Marketing, 28(1), 82-94.

Giddens, A. (1991). Modernity and self-identity: Self and society in the late modern age. Stanford University Press.

Goetzke, B., Nitzko, S., \& Spiller, A. (2014). Consumption of organic and functional food. A matter of well-being and health?. Appetite, 77, 96-105.

Grunert, K. G. (2002). Current issues in the understanding of consumer food choice. Trends in Food Science \& Technology, 13(8), 275-285.

Hansen, T., Mukherjee, A., \& Uth Thomsen, T. (2011). Anxiety and search during food choice: The moderating role of attitude towards nutritional claims. Journal of Consumer Marketing, 28(3), 178-186.

Hartman, L. M. (1986). Social anxiety, problem drinking, and self-awareness. in Perception of Self in Emotional Disorder and Psychotherapy, eds. L. M. Hartman, \& K. R. Blankstein, (265-282), New York: Plenum Press,

Hettler, B. (1984). Wellness: encouraging a lifetime pursuit of excellence. Health Values, 8(4), 13-17.

Hudson, S., Huang, L., Roth, M. S., \& Madden, T. J. (2016). The influence of social media interactions on consumer-brand relationships: A three-country study of brand perceptions and marketing behaviors. International Journal of Research in Marketing, 33(1), 27-41.

Hwang, Y., \& Kim, D. J. (2007). Customer self-service systems: The effects of perceived Web quality with service contents on enjoyment, anxiety, and e-trust. Decision Support Systems, 43(3), 746-760.

Jackson, P. (2010). Food stories:Cconsumption in an age of anxiety. Cultural Geographies, 17(2), 147-165.

Jensen Schau, H., \& Gilly, M. C. (2003). We are what we post? Self-presentation in personal web space. Journal of Consumer Research, 30(3), 385-404.

Kaplan, A. M., \& Haenlein, M. (2010). Users of the world, unite! The challenges and opportunities of Social Media. Business Horizons, 53(1), 59-68.

Kemp, S. (2019). "Digital 2019: Turkey." Datareportal global digital insights, datareportal - global digital insights, 31 Jan. 2019, datareportal.com/reports/ digital-2019-turkey?rq=turkey.
Keng, C. J., \& Liao, T. H. (2013). Self-confidence, anxiety, and post-purchase dissonance: a panel study. Journal of Applied Social Psychology, 43(8), 1636-1647.

Kjaernes, U. \& Torjusen, H., (2012). Beyond the industrial paradigm? Consumers and trust in food. in Food practices in Transition: Changing Food Consumption, Retail and Production in the Age of Reflexive Modernity (106-126). USA: Routledge.

King, S. C., Snow, J., Meiselman, H. L., Sainsbury, J., Carr, B. T., McCafferty, D., ... \& Li, Q. (2015). Development of a questionnaire to measure consumer wellness associated with foods: The WellSense profile ${ }^{\mathrm{TM}}$. Food Quality and Preference, 39, 82-94.

Koc, M., \& Gulyagci, S. (2013). Facebook addiction among Turkish college students: The role of psychological health, demographic, and usage characteristics. Cyberpsychology, Behavior, and Social Networking, 16(4), 279-284.

Korda, H., \& Itani, Z. (2013). Harnessing social media for health promotion and behavior change. Health Promotion Practice, 14(1), 15-23.

Kross, E., Verduyn, P., Demiralp, E., Park, J., Lee, D. S., Lin, N., ... \& Ybarra, O. (2013). Facebook use predicts declines in subjective well-being in young adults. PloS one, 8(8), e69841.

Kuhlmeier, D., \& Knight, G. (2005). Antecedents to internet-based purchasing: a Multinational study. International Marketing Review, 22(4), 460-473.

Lee, K., Kim, H., \& Vohs, K. D. (2011). Stereotype threat in the marketplace: Consumer anxiety and purchase intentions. Journal of Consumer Research, 38(2), 343357.

Liebowitz, M. R. (1987). Social phobia. Modern problems of Pharmacopsychiatry, 22, 141-173.

Liu, C., Ang, R. P., \& Lwin, M. O. (2013). Cognitive, personality, and social factors associated with adolescents' online personal information disclosure. Journal of Adolescence, 36(4), 629-638.

Locander, W. B., \& Hermann, P. W. (1979). The effect of self-confidence and anxiety on information seeking in consumer risk reduction. Journal of Marketing Research, 16(2), 268-274.

Lovibond, P. F., \& Lovibond, S. H. (1995). The structure of negative emotional states: Comparison of the depression anxiety stress scales (DASS) with the beck depression and anxiety inventories. Behaviour Research and Therapy, 33(3), 335-343.

Lowe, P., Phillipson, J., \& Lee, R. P. (2008). Socio-technical innovation for sustainable food chains: roles for 
social science. Trends in Food Science \& Technology, 19(5), 226-233.

Luce, M. F., Bettman, J. R., \& Payne, J. W. (2001). Minimizing negative emotion as a decision goal: investigating emotional trade-off difficulty. in The Why of Consumption: Contemporary Perspectives on Consumers Motives, Goals, and Desires. eds. S. Ratneshwar, Huffman C., Mick D.G., 57-78, London: Routledge.

Mattick, R. P., \& Clarke, J. C. (1998). Development and validation of measures of social phobia scrutiny fear and social interaction anxiety. Behaviour Research and Therapy, 36(4), 455-470.

McKinley, C. J., \& Wright, P. J. (2014). Informational social support and online health information seeking: Examining the association between factors contributing to healthy eating behavior. Computers in Human Behavior, 37, 107-116.

McGill, A. E. (2009). The potential effects of demands for natural and safe foods on global food security. Trends in Food Science \& Technology, 20(9), 402-406.

McMahon, A. T., Williams, P., \& Tapsell, L. (2010). Reviewing the meanings of wellness and well-being and their implications for food choice. Perspectives in Public Health, 130(6), 282-286.

Meiselman, H. L. (2016). Quality of life, well-being and wellness: Measuring subjective health for foods and other products. Food Quality and Preference, 54, 101-109.

Meuter, M. L., Ostrom, A. L., Bitner, M. J., \& Roundtree, R. (2003). The influence of technology anxiety on consumer use and experiences with self-service technologies. Journal of Business Research, 56(11), 899-906.

Oberst, U., Wegmann, E., Stodt, B., Brand, M., \& Chamarro, A. (2017). Negative consequences from heavy social networking in adolescents: The mediating role of fear of missing out. Journal of Adolescence, $55,51-60$.

Piamphongsant, T., \& Mandhachitara, R. (2008). Psychological antecedents of career women's fashion clothing conformity. Journal of Fashion Marketing and Management: An International Journal, 12(4), 438-455.

Price, L. L., \& Arnould, E. J. (2003). Authenticating acts and authoritative performances: Questing for self and community. in The Why of Consumption: Contemporary Perspectives on Consumers Motives, Goals, and Desires. eds. S. Ratneshwar, Huffman C., Mick D.G., 138-162, London: Routledge.
Raacke, J., \& Bonds-Raacke, J. (2008). MySpace and Facebook: Applying the uses and gratifications theory to exploring friend-networking sites. Cyberpsychology \& Behavior, 11(2), 169-174.

RSPH (2017, May 19). Instagram ranked worst for young people's mental health, Retrieved from the RSPH: https://www.rsph.org.uk/about-us/news/ instagram-ranked-worst-for-young- people-s-mental-health.html

Ryan, T., \& Xenos, S. (2011). Who uses facebook? An investigation into the relationship between the big five, shyness, narcissism, loneliness, and Facebook usage. Computers in Human Behavior, 27(5), 16581664.

Scholten, S., Velten, J., Bieda, A., Zhang, X. C., \& Margraf, J. (2017). Testing measurement invariance of the depression, anxiety, and stress scales (DASS-21) across four countries. Psychological Assessment, 29(11), 1376.

Sekaran, U., \& Bougie, R. (2016). Research methods for business: A skill building approach. John Wiley \& Sons.

Schuster, T. L., Dobson, M., Jauregui, M., \& Blanks, R. H. (2004). Wellness lifestyles I: A theoretical framework linking wellness, health lifestyles, and complementary and alternative medicine. The Journal of Alternative \& Complementary Medicine, 10(2), 349-356.

Sego, T., \& Stout, P. A. (1994). Anxiety associated with social issues: The development of a scale to measure an antecedent construct. eds. Allen C. T. and John D.R. in NA - Advances in Consumer Research (21), 601606. Provo, UT : Association for Consumer Research.

Spaargaren, G., Loeber, A. \& Oosterveer, P., (2012). Food Futures in the Making, in Food practices in transition: changing food consumption, retail and production in the age of reflexive modernity.eds. Spaargaren, G., Oosterveer, P., \& Loeber, A., 312-338, New York: Routledge.

Suranyi-Unger Jr, T. (1981). Consumer behavior and consumer well-being: An economist's digest. Journal of Consumer Research, 8(2), 132-143.

Sweeney, J. C., Hausknecht, D., \& Soutar, G. N. (2000). Cognitive dissonance after purchase: A multidimensional scale. Psychology \& Marketing, 17(5), 369-385.

Thomée, S., Eklöf, M., Gustafsson, E., Nilsson, R., \& Hagberg, M. (2007). Prevalence of perceived stress, symptoms of depression and sleep disturbances in relation to information and communication technology (ICT) use among young adults. Computers in Human Behavior, 23(3), 1300-1321. 
Thomson, M., \& Johnson, A. R. (2002). Investigating the role of attachment dimensions as predictors of satisfaction in consumer-brand relationships. eds. Broniarczyk S.M. and Nakamoto K., in NA-Advances in Consumer Research (29), 42. Valdosta, GA: Association for Consumer Research.

Valence, G., d'Astous, A., \& Fortier, L. (1988). Compulsive buying: Concept and measurement. Journal of Consumer Policy, 11(4), 419-433.

Vaterlaus, J. M., Patten, E. V., Roche, C., \& Young, J. A. (2015). \#Gettinghealthy: The perceived influence of social media on young adult health behaviors. Computers in Human Behavior, 45, 151-157.

Veenhoven, R. (2000). The four qualities of life. Journal of Happiness Studies, 1(1), 1-39.

Woods, H. C., \& Scott, H. (2016). \#Sleepyteens: Social media use in adolescence is associated with poor sleep quality, anxiety, depression and low self-esteem. Journal of Adolescence, 51, 41-49.

Yao, C., \& Liao, S. (2011). Measuring the antecedent effects of service cognition and internet shopping anxiety on consumer satisfaction with e-tailing service. Management \& Marketing, 6(1).

Zilberman, D., \& Kaplan, S. (2014). What the adoption literature can teach us about social media and network effects on food choices. In 2014 AAEA/EAAE/ CAES Joint Symposium: Social Networks, Social Media and the Economics of Food, Montreal, Canada (No. 173076). Canada: Agricultural and Applied Economics Association \& Canadian Agricultural Economics Society \& European Association of Agricultural Economists. 